\title{
REASONS FOR SMOKING AMONG ENGLISH- SPEAKING ADULTS IN LEICESTER - A PILOT STUDY
}

\begin{abstract}
Cigarette smoke contains around 7000 chemicals that are harmful to health and cause premature death. Most smokers acknowledge the harm they are doing to them yet continue to smoke. This pilot study was designed to understand the impact of cigarette smoking, the addictive effect of nicotine, and also to hypothesize a recommendation for smoking cessation.

Methods: This study recruited English speaking adult participants who were either current, occasional, and ex-smokers from NHS Stop Smoking clinics in Leicester, United Kingdom, using a selfcompleted questionnaire.

Results: Out of 32 participants, white British and Asian were top two ethnicities with majority of males as respondents. Stress, boredom, nervousness, and 'just like it', were the main reasons quoted for cigarette smoking. Irritation \& mood swings were top reasons for craving. The visual stimuli and 'smell of smoking' were reported as top two strong cues. Majority of the participants reported having several health problems mainly due to cigarette smoking such as respiratory cough, feel like tightening of lungs, asthma, high blood pressure, difficulty in losing weight, excess fat accumulation near waist, poor appetite, fatigue, sleeping disturbances, darkened teeth as well as an inability to differentiate between taste.

Conclusion: Our study suggested that cigarette smoking maybe more like a habit than an addiction. which unable to relieve stress or boredom but keeps smoker hooked to the habit.

Keywords

Cigarette smoking, health impact, behaviour, smoking cessation.
\end{abstract}

Kshama R. Joshi, Ruta Furmonaviciene

Department of Biomedical Science \& Immunology, De Montfort University, Leicester, UK

Correspondence to: kshamarjoshi@gmail.com

DOI:

https://doi.org/10.38192/13.3.16

Article Information

$\begin{array}{ll}\text { Submitted } & 14.08 .2020 \\ \text { Pre-print } & 15.08 .2020 \\ \text { Revised } & 22.08 .2020\end{array}$

Open Access - Creative Commons Licence CC-BY-ND-4.0

\section{BACKGROUND}

Smoking is the biggest cause of preventable deaths across the globe killing approximately 8 million individuals. Interestingly 7 million individuals' death resulted from direct smoking, but 1.2 million non-smokers lost their life due to second-hand smoking. [1] Smoking is a practice by which tobacco gets burned, and the resulting smoke gets inhaled in to be tasted and absorbed into the bloodstream. The most common substance used for smoking is the dried leaves of the tobacco plant. Smoking, sniffing, or chewing are considered the most common ways to consume tobacco. Tobacco smoking caused premature death among approximately 6 million people worldwide [2] and about 96,000 people every year in the UK. [3]

In the United Kingdom, the Policy Exchange Report of 2010 states that the total cost of smoking to society and the economy was GBP $£ 13.4$ billion. [4] Various fiscal, legal restriction, and intervention measures were adopted to stop 
the availability and spread of this harmful addiction. Despite these comprehensive measures, 1 in 5 people still smoke. [5] Leicester City Clinical Commissioning Group (LCCG) suggested national smoking prevalence estimated at $17.3 \%$ for Leicester, which is statistically higher than the national rate (14.4\%). Further, it suggested that smoking prevalence among Leicester males (21\%) and females $(13.6 \%)$ is significantly higher as compared to England males (16.4\%) and females (12.6\%). [6]

\section{Effects on health}

Tobacco smoking results in respiratory, cardiovascular, and malignant diseases. 'Stop Smoking' considered being a key medical intervention to curb tobacco dependence. However, the addictive properties of cigarette smoking, especially nicotine inhalation, leave smokers quitting attempts unsuccessful. The continuous use of cigarettes leads to addiction among many users. Nicotine is one of the proven addictive drugs, which is more addictive than heroin, and cocaine. [7] Despite knowing that smoking is bad for health, smokers failed to give up the habit which clearly emphasize addiction towards nicotine. Nicotine craving activates the dopamine reward pathway in smokers. Failure to supply nicotine when the body craves for it, leads to withdrawal symptoms, which slows the smoking cessation rate. Hence, to handle this domino effect, it is essential to address the withdrawal symptoms, as well as the time window between two cigarettes. These two aspects will give rise to an effective novel way to enhance the cessation rate. Hence it is essential to understand the behavioural changes in smokers to curb smoking habits. [8-10]

Many cigarette smokers continuing cigarette smoking as they believe that cigarettes help them to deal with stress, boredom and/or they 'just like it'. Conversely, cigarette smoking does not relieve stress and/or boredom. It makes the smoker hooked to the habit of smoking, where the smoker feel the need to take specific amounts of nicotine rush every time 'to feel normal'.

The relationship between cigarette smoking and its cariogenic effects are widely known however, the deleterious impact of cigarette smoke on other organs and immune system are not widely known. Following table 1 illustrated a brief overview of ten harmful chemicals found in cigarette and its associated symptom, possible diseases, its impact on the immune system, behavioural changes, and ultimately affecting vital organs.

Interventions are also necessary to effectively handle the 'window time' between two cigarettes. Current information suggested that smoking cessation treatments are not yet costeffective, primarily due to the high price of tobacco replacement products. It prompts to develop a cost-effective intervention, which will provide a strong pillar to curb tobacco consumption via interventions. This approach needs to cater at an individual level. [11]

Various novel approaches are being subjected to current studies such as rimonabant based novel approach to Stop Smoking, the use of selegiline based therapeutic agent in curbing the smoking habit and immunomodulation via vaccination is gaining an increasing level of attention from a wider research community.

Governments all over the world and especially in UK has introduced various measures to curb smoking. These measures range from imposing higher taxes on tobacco products, introducing a ban on advertising, display materials promoting tobacco, cigarette smoking, and to engage in hosting Stop-Smoking clinics under the NHS flag. Though these programs are showing some significant results, there is still more to be done.

Nicotine replacement products are currently available to all smokers who showed interest in NHS Stop Smoking initiatives. The proposed hypothesis suggests as cigarette smoking is due to habit and not because of addiction. Under the long tail phenomenon, smokers who smoke due to addiction fall in a small group (towards the tail) as compared to the smokers who smoke due to habit. Therefore, by chopping off the large chunk of smokers who continue smoking due to sheer habit will have only qualified access to subsidize nicotine replacement products. In addition, the focus can be shifted from an approach of prescribing nicotine replacement products to inventing more innovative ways to deal with the boredom, which was one of the main reasons for many heavy smokers to engage in smoking behaviour. It will ease of NHS budget 
to a certain extent. However, Smokers who smoke under addiction need to be treated more effectively and carefully to improve smoking cessation.

\section{Methods}

This pilot study was conducted under academic activity, performed with limited resources, money, and time. As a result, this study was completed within a small sample size with a pragmatic approach. [12] Participation in this study was voluntary. This study was conducted at three different NHS Stop Smoking clinics within Leicester, with 32 respondents (twentythree males and nine females) who were either current, occasional, or ex-smokers. Participants from varied ethnicities and with the age limit between 18 to 85 years from Leicester were included in this study.

The self-completing questionnaire method was used to get insights from the respondents, mainly to understand the respondent's lifestyle choices towards smoking, exercise, diet, and its impact on their physiological and psychological health. The questions also gave straightforward information and facts about various diseases/ disorders and symptoms those individuals were experiencing.

Due to the sensitive nature of the study, age, gender, ethnicities were asked, but the name of the respondents was not requested. A participation information sheet (PIS) was provided to all participants before participation to explain the scope of the study. Each participant's consent was gained before the study. A self-completed questionnaire in printout form was deployed to gain the optimum response during the survey. There were total 7 questions in the questionnaire, which required approximately 7-10 minutes to complete (per participant).

Smoking is considered a sensitive topic, especially in the case of a person's health. Therefore, this study gained De Montfort university ethic committee's approval (on 20 August 2013) and consents from all stakeholders before recruiting respondents.

\section{Confidentiality \& Data protection}

The information collected was used in an aggregated form to conclude. The collected paper data was stored in the lock and key, and the digital data was stored on the university cloud. Only the researcher and authorized personnel will have access to the surveyed information. This research adhered to all the laws and requirements of the Data Protection Act 1998, grants personal data processing privacy to the individual as well as De Montfort University established rules and guidelines for collecting, storing, and disposing of the data.

\section{Research venues and duration}

The total study duration from conceptualization to submitting a thesis happened under seven months. The research was conducted at the following three venues, such as Stop Smoking clinics at Boots Oadby, Highem pharmacy and Leicester Railway Station. (As part of public awareness, the Stop Smoking initiative was organized to install a Stop Smoking desk at Leicester Railway Station).

\section{Results}

This pilot study indicates that smokers do tend to show similar illnesses and health effects, as outlined in the literature review. A total of thirtytwo participants participated in this study, including nine females and twenty-three males. The top two ethnicities were White British and Asian, with 13 \& 9 participants, respectively. Majority of the participants were reported to consume over ten cigarettes per day.

Surprisingly, these heavy smokers were found to be engaged in some form of exercise. It was observed that "stress, boredom, and just like it" were the leading top three reasons behind the consumption of cigarette smoking. Irritation and mood swings were top two reasons for craving for cigarette smoking observed among heavy smokers (who smoke over ten cigarettes per day).

Visual stimuli and smell of smoking were reported as top cues for smoking. Respiratory cough feels like tightening of lungs, and asthma were highest observed effects under respiratory system. High cholesterol and high blood pressure were highest observed effects under cardiovascular system. Respondents suggested various issues related to gastrointestinal disorders. Poor appetite and excess fat 
accumulation around the waist and difficulty in losing weight were some of the prominent effects in case of gastrointestinal system. Fatigue and sleep disturbances were observed among studied cohort. Darkened teeth, bad breath and an inability to differentiate between the taste were the most observed effects in case of Ear, Nose and Throat (ENT) and oral health.

As per the existing literature, smokers do not follow a healthy diet and a regular exercise pattern. However, this pilot study reveals that smokers followed a relatively healthy diet, and they were engaged in regular exercise.

To enhance cessation rate, it is important to address the withdrawal symptoms, as well as to handle the time window between two cigarettes to delink the vicious circle of cigarette smoking.

While most of the key findings support the available literature review on the deleterious impact of cigarette smoke, responses on 'reasons for smoking' from heavy smokers $(10+$ cigarettes/day) is providing a basis for formulating a new hypothesis that smoking is more like a habit than an just an addiction.

\section{Limitation and future study}

This pilot study was conducted with a small number of participants using NHS Stop Smoking clinic umbrella at three different locations within Leicester. The maximum numbers of the respondents were recruited from Leicester Rail station's Stop Smoking clinic site. The recruitment day was a declared school holiday due to which a large proportion of professionals may be working from home, attending their children. It might lead to a biased sample as this was possibly less representative of commuters at all timings, which mean the professionals who would commute to work, or return would not have received adequate representation. Females representation was less as compared to males. All respondents were from one geographical area which was Leicester, UK, instead of diverse. Further research is warranted within nonsmokers to compare the results. Therefore, future study needs factor such limitations during project planning phase and ensure a larger sample size with well-rounded recruitment strategy.
References

1. World Health Organization (2020) Tobacco. [Online] WHO. Available from:

https://www.who.int/news-room/factsheets/detail/tobacco [ Accessed 05.07.20].

2. World Health Organization (2013). WHO report on the global tobacco epidemic, 2013: enforcing bans on tobacco advertising, promotion, and sponsorship. Geneva: WHO.

3. Action on Smoking and Health (2016). Smoking statistics: Who smokes and how much? London: ASH; Retrieved from http://www.ash.org.uk/files/documents /ASH_106.pdf

4. Action on Smoking and Health (ASH) (2013) The Economics of Tobacco. Government of the United Kingdom.

5. HM Government (2010) Healthy Lives, Healthy People: Our Strategy for public health in England. London: Department of health.

6. Leicester City Clinical Commissioning Group (2020) Tobacco [WWW] LCCG. Available from: https://www.leicester.gov.uk/media/186431 /tobacco-jsna-chapter-2020.pdf [ Accessed 31.07.20].

7. University of Minnesota (2003) Nicotine Addiction [WWW] University of Minnesota. Available from: http://www1.umn.edu/perio/tobacco/nicadd ct.html [Accessed 12.10.2013].

8. NINEHAM, L. (2010) Habit not addiction that fuels cigarette cravings [WWW] The stop smoking lounge. Available from: http://www.thestopsmokinglounge.com/smo king-hypnosis-news /4846/habit-notaddiction-that-fuels-cigarette-cravings/ [Accessed 11.11.2013].

9. Ussher M., Brown J., Rajamanoharan A., \& West R. (2014). How do prompts for attempts to quit smoking relate to method of quitting and quit success? ANNALS OF BEHAVIORAL MEDICINE, , 358-368.

10. Fidler J., \& West R. (2011). Enjoyment of smoking and urges to smoke as predictors of attempts and success of attempts to stop smoking: A longitudinal study. DRUG AND ALCOHOL DEPENDENCE, 30-34.

11. TOBIAS, R. et al. (2012) Nicotine Vaccines to Assist with Smoking Cessation: Current Status of Research. Adis international, 72, pp. e1-e16.

12. DENSCOMBE, M. (2010) The Good Research Guide: For small- scale social research projects. Open University Press, (4).

13. Qiu, F., Liang, C.-L., Liu, H., Zeng, Y.-Q., Hou, S., Huang, S., ... Dai, Z. (2017). Oncotarget 268 www.impactjournals.com/oncotarget Impacts of cigarette smoking on immune responsiveness: Up and down or upside down? 
Sushruta Journal of Health Policy \& Opinion

Oncotarget, 8(1), 268-284.

14. DUTTA, N. (2013) World No Tobacco Day2013: 10 dangerous chemicals in cigarettes [WWW] Health. Available from: http://health.india.com/diseasesconditions/world-no-tobacco-day-2013-10dangerous-chemicals-in-cigarettes/ [Accessed 02/09/2013].

15. Di Chiara, G. (2000). Role of dopamine in the behavioural actions of nicotine related to addiction. European Journal of Pharmacology, 393(1-3), 295-314. https://doi.org/10.1016/S00142999(00)00122-9.

16. Smith, M. T. (2010). Advances in understanding benzene health effects and susceptibility. Annual Review of Public Health, 31, 133-148.

17. Gillis, B., Gavin, I. M., Arbieva, Z., King, S. T., Jayaraman, S., \& Prabhakar, B. S. (2007). Identification of human cell responses to benzene and benzene metabolites. Genomics, 90(3), 324-333.

18. Mehta, H., Nazzal, K., \& Sadikot, R. T. (2008). Cigarette smoking and innate immunity. Inflammation Research, 57(11), 497-503. https://doi.org/10.1007/s00011-008-8078-6

19. Kosmider, L., Cox, S., Zaciera, M., Kurek, J., Goniewicz, M. L., McRobbie, H., ... Dawkins, L. (2020). Daily exposure to formaldehyde and acetaldehyde and potential health risk associated with use of high and low nicotine eliquid concentrations. Scientific Reports, 10(1), 1-10. https://doi.org/10.1038/s41598-02063292-1

20. Campbell, R. C. J., Stephens, W. E., \& Meharg, A. A. (2014). Consistency of arsenic speciation in global tobacco products with implications for health and regulation. Tobacco Induced Diseases, 12(1), 1-8. https://doi.org/10.1186/s12971-014-0024-5

21. Pappas, R. S., Fresquez, M. R., Watson, C. H., Branch, V., \& Services, A. (2016). Filters: Implications for Exposure, 39(1), 45-51. https://doi.org/10.1093/jat/bku115.Cigarette

22. Ganguly, K., Levänen, B., Palmberg, L., Åkesson, A., \& Lindén, A. (2018). Cadmium in tobacco smokers: A neglected link to lung disease? European Respiratory Review, 27(147), 1-8.

23. Seeman, J. I., \& Carchman, R. A. (2008). The possible role of ammonia toxicity on the exposure, deposition, retention, and the bioavailability of nicotine during smoking. Food and Chemical Toxicology, 46(6), 1863-1881. https://doi.org/10.1016/j.fct.2008.02.021

24. Mahernia, S., Amanlou, A., Kiaee, G., \& Amanlou, M. (2015). Determination of hydrogen cyanide concentration in mainstream smoke of tobacco products by polarography. Journal of Environmental Health Science and Engineering, 13(1), 1-6. https://doi.org/10.1186/s40201015-0211-1

25. Zevin, S., Saunders, S., Gourlay, S. G., Jacob, P., \& Benowitz, N. L. (2001). Cardiovascular effects of carbon monoxide and cigarette smoking. Journal of the American College of Cardiology, $38(6)$, 1633-1638. https://doi.org/10.1016/S07351097(01)01616-3

26. Brown, B. G., Borschke, A. J., \& Doolittle, D. J. (2003). An Analysis of the Role of TobaccoSpecific Nitrosamines in the Carcinogenicity of Tobacco Smoke. Nonlinearity in Biology, Toxicology, Medicine. https://doi.org/10.1080/1540142039143432 $\underline{4}$

27. Muggli, M. E., Ebbert, J. O., Robertson, C., \& Hurt, R. D. (2008). Waking a sleeping giant: The tobacco industry's response to the polonium210 issue. American Journal of Public Health, 98(9), 1643-1650. https://doi.org/10.2105/AJPH.2007.130963

28. Zagà, V., Lygidakis, C., Chaouachi, K., \& Gattavecchia, E. (2011). Polonium and lung cancer. Journal of Oncology, 2011. https://doi.org/10.1155/2011/860103

29. Bernhard, D., Rossmann, A., \& Wick, G. (2005). Metals in cigarette smoke. IUBMB Life, 57(12), 805-809. https://doi.org/10.1080/1521654050045966 7

Authors declare no conflict of interest The study was approved by Institutional Ethics Committee 
Sushruta Journal of Health Policy \& Opinion

\begin{tabular}{|c|c|c|c|c|c|c|}
\hline $\begin{array}{l}\text { Chemica } \\
\text { ls in } \\
\text { cigarett } \\
\text { e }\end{array}$ & Symptoms & Diseases & $\begin{array}{l}\text { Impact on the } \\
\text { Immune system }\end{array}$ & $\begin{array}{c}\text { Impact on } \\
\text { behavioral } \\
\text { change }\end{array}$ & $\begin{array}{c}\text { Impact on vital } \\
\text { organ }\end{array}$ & Reference \\
\hline Nicotine & $\begin{array}{l}\text { Constricts veins } \\
\text { and arteries, } \\
\text { deposits } \\
\text { cholesterol and } \\
\text { fat into the } \\
\text { bloodstream } \\
\text { leading to blood } \\
\text { clots }\end{array}$ & $\begin{array}{l}\text { Blood pressure, } \\
\text { diabetes, coronary } \\
\text { artery constriction, } \\
\text { increased or } \\
\text { decreased heart rate, } \\
\text { gastrointestinal } \\
\text { problems }\end{array}$ & $\begin{array}{l}\text { Alters immune } \\
\text { responses by directly } \\
\text { interacting with T } \\
\text { cells, as well as } \\
\text { indirectly through } \\
\text { brain-immune } \\
\text { interactions }\end{array}$ & $\begin{array}{l}\text { Irritability, } \\
\text { dizziness, } \\
\text { insomnia, light- } \\
\text { headedness }\end{array}$ & $\begin{array}{l}\text { Heart-Brain, lungs, } \\
\text { Gastrointestinal } \\
\text { tract, Endocrine }\end{array}$ & $\begin{array}{l}{[13,14,} \\
15]\end{array}$ \\
\hline Benzene & $\begin{array}{l}\text { Paralysis, } \\
\text { convulsions, } \\
\text { tremors, } \\
\text { dizziness, coma, } \\
\text { sleepiness, } \\
\text { tightness in the } \\
\text { chest, anemia }\end{array}$ & $\begin{array}{l}\text { Leukemia (acute } \\
\text { myeloid leukemia } \\
\text { (AML), aplastic } \\
\text { anemia, } \\
\text { myelodysplastic } \\
\text { syndrome (MDS), } \\
\text { acute lymphoblastic } \\
\text { leukemia (ALL), and } \\
\text { chronic myeloid } \\
\text { leukemia (CML), } \\
\text { damage to CNS }\end{array}$ & $\begin{array}{l}\text { Abnormal sperm } \\
\text { count impacting } \\
\text { fertility and fetal } \\
\text { development, neural } \\
\text { congenital } \\
\text { disabilities spina } \\
\text { bifida and } \\
\text { anencephaly }\end{array}$ & $\begin{array}{l}\text { Blind, deaf and no } \\
\text { sense of pain }\end{array}$ & $\begin{array}{l}\text { Chromosomal } \\
\text { aberrations and } \\
\text { Bone marrow } \\
\text { cancer }\end{array}$ & $\begin{array}{l}{[16,17,} \\
14]\end{array}$ \\
\hline $\begin{array}{l}\text { Formald } \\
\text { ehyde }\end{array}$ & $\begin{array}{l}\text { Irritation to eyes, } \\
\text { nose, and throat, } \\
\text { nausea, } \\
\text { wheezing, skin } \\
\text { irritations }\end{array}$ & $\begin{array}{l}\text { Nasal cancer, } \\
\text { Nasopharyngeal } \\
\text { cancer }\end{array}$ & $\begin{array}{l}\text { Alters the chemical } \\
\text { structure of DNA }\end{array}$ & $\begin{array}{l}\text { Asthma (breathing } \\
\text { problem) }\end{array}$ & $\begin{array}{l}\text { Upper respiratory } \\
\text { tract, Nose, } \\
\text { pharynxes }\end{array}$ & $\begin{array}{l}{[18,19,} \\
14]\end{array}$ \\
\hline Arsenic & $\begin{array}{l}\text { Damage to } \\
\text { kidneys, liver, } \\
\text { bladder, skin, } \\
\text { lungs }\end{array}$ & Skin and Lung cancer & $\begin{array}{l}\text { Alters the pathway of } \\
\mathrm{T} \text { helper cells, leading } \\
\text { to cell death and } \\
\text { inadequate immune } \\
\text { response }\end{array}$ & $\begin{array}{l}\text { Inhibits } \\
\text { Mononuclear cells } \\
\text { and alters cytokine } \\
\text { secretion, changing } \\
\text { CD4/CD8 cells } \\
\text { ratio resulting } \\
\text { immunosuppressio } \\
\mathrm{n}\end{array}$ & Skin and Lungs & {$[20,14]$} \\
\hline $\begin{array}{l}\text { Cadmiu } \\
\text { m }\end{array}$ & $\begin{array}{l}\text { Nausea, } \\
\text { vomiting, shock, } \\
\text { convulsions, } \\
\text { muscle cramps, } \\
\text { sensory } \\
\text { disruptions, lung } \\
\text { disease }\end{array}$ & $\begin{array}{l}\text { Renal cell cancer, } \\
\text { prostate, and } \\
\text { colorectal cancer }\end{array}$ & $\begin{array}{l}\text { Transformation of } \\
\text { epithelial cells into } \\
\text { cancer cells after } \\
\text { repetitive exposure }\end{array}$ & $\begin{array}{l}\text { Oxidative stress, } \\
\text { inhibition of DNA } \\
\text { repairs } \\
\text { mechanisms, and } \\
\text { augmenting or } \\
\text { diminishing the } \\
\text { tendency to } \\
\text { apoptosis. }\end{array}$ & $\begin{array}{l}\text { Kidney, Prostate, } \\
\text { and Breast }\end{array}$ & $\begin{array}{l}{[21,14,} \\
22]\end{array}$ \\
\hline $\begin{array}{l}\text { Ammoni } \\
\text { a }\end{array}$ & Damage to lungs & Lung cancer & $\begin{array}{l}\text { Nicotine absorption } \\
\text { alters }\end{array}$ & $\begin{array}{l}\text { Get accumulated in } \\
\text { lungs and } \\
\text { bronchitis }\end{array}$ & $\begin{array}{l}\text { Lungs finally } \\
\text { leading to Death }\end{array}$ & {$[23,14]$} \\
\hline $\begin{array}{l}\text { Hydroge } \\
\text { n } \\
\text { cyanide }\end{array}$ & $\begin{array}{l}\text { Headaches, } \\
\text { weakness, } \\
\text { dizziness, } \\
\text { irregular } \\
\text { heartbeats, } \\
\text { fainting, } \\
\text { vomiting, and } \\
\text { nausea }\end{array}$ & $\begin{array}{l}\text { Lung injury, } \\
\text { respiratory failure }\end{array}$ & $\begin{array}{l}\text { No change on the } \\
\text { Immune system }\end{array}$ & Cilia Toxic & $\begin{array}{l}\text { Brain, heart and } \\
\text { nervous system } \\
\text { damage, coma and } \\
\text { Leading to Death }\end{array}$ & {$[24,14]$} \\
\hline $\begin{array}{l}\text { Carbon } \\
\text { monoxi } \\
\text { de }\end{array}$ & $\begin{array}{l}\text { Chest pain, } \\
\text { dizziness, } \\
\text { confusion, } \\
\text { vomiting, nausea, } \\
\text { disorientation, } \\
\text { loss of } \\
\text { consciousness, } \\
\text { cardiovascular } \\
\text { effects }\end{array}$ & $\begin{array}{l}\text { Decreased blood } \\
\text { pressure, oxygen } \\
\text { deficiency (hypoxia), } \\
\text { pulmonary damage, } \\
\text { loss of elasticity in } \\
\text { the alveoli }\end{array}$ & $\begin{array}{l}\text { No effect on Immune } \\
\text { system }\end{array}$ & $\begin{array}{l}\text { Chest pain, } \\
\text { dizziness, } \\
\text { confusion, } \\
\text { vomiting, nausea, } \\
\text { disorientation, loss } \\
\text { of consciousness }\end{array}$ & $\begin{array}{l}\text { Blood clots, } \\
\text { (Thrombosis), } \\
\text { stroke, Leading to } \\
\text { Death }\end{array}$ & {$[25,14]$} \\
\hline
\end{tabular}


Sushruta Journal of Health Policy \& Opinion

\begin{tabular}{|c|c|c|c|c|c|c|}
\hline $\begin{array}{l}\text { Tobacco } \\
\text { specific } \\
\text { nitrosa } \\
\text { mines } \\
\text { (TSNA) }\end{array}$ & $\begin{array}{l}\text { Ulcers in mouth, } \\
\text { Pancreas, Lungs, } \\
\text { esophagus, and } \\
\text { Liver }\end{array}$ & Oral and Lung Cancer & $\begin{array}{l}\text { Methyl and } \\
\text { pyridyloxobutyl DNA } \\
\text { adducts }\end{array}$ & Ulcers & $\begin{array}{l}\text { Lung, esophagus, } \\
\text { pancreas, and oral } \\
\text { cavity }\end{array}$ & {$[26,14]$} \\
\hline $\begin{array}{l}\text { Poloniu } \\
\text { m and } \\
\text { lead }\end{array}$ & $\begin{array}{l}\text { Radioactive hot } \\
\text { spots }\end{array}$ & Lung Cancer & $\begin{array}{l}\text { Damage to cell cycle, } \\
\text { from squamous cell } \\
\text { to adenocarcinoma }\end{array}$ & Irritation to skin & Lung & $\begin{array}{l}{[27,14,28,} \\
29]\end{array}$ \\
\hline
\end{tabular}

